\title{
Decreased bull fertility: age-related changes in sperm motility and DNA fragmentation
}

\author{
Berlin P. Pardede ${ }^{1}$, Iman Supriatna ${ }^{2}$, Yudi Yudi $^{2}$, and Muhammad Agil2* \\ ${ }^{1}$ Reproductive Biology Study Program, Faculty of Veterinary Medicine, Graduate School of IPB University, Bogor, \\ Indonesia. \\ ${ }^{2}$ Division of Reproduction and Obstetrics, Department of Veterinary Clinic, Reproduction and Pathology, Faculty \\ of Veterinary Medicine, IPB University, Bogor, Indonesia.
}

\begin{abstract}
This study aimed to analyze the effect of the age of bulls on sperm motility and DNA fragmentation and its impact on fertility. Ninety-six frozen semen straw from eight bulls were divided into four groups based on age (group-1: 5-6 years; group-2: 7-8 years; group-3: 9-10 years; group-4: 11-12 years). Total and progressive motility were detected by using computer-assisted semen analysis (CASA), while DNA fragmentation was detected by Toluidine blue staining. Over 500 artificial insemination services in the field were used for fertility rate analysis. The results of the analysis of total motility, progressive, and DNA fragmentation in all age groups still meet the minimum standard for artificial insemination programs. Analysis of progressive motility and DNA fragmentation showed significant differences in each age group $(\mathrm{P}<0.01)$, whereas analysis of total motility showed no significant differences in group-2 (7-8 years) and group-3 (9-10 years) $(\mathrm{P}>0.01)$. Increased age in bulls correlated significantly with increased sperm DNA fragmentation $(\mathrm{P}<0.01)$, decreased total and progressive motility $(\mathrm{P}<0,01)$, and potentially reduced the fertility rate $(\mathrm{P}<0.01)$. In conclusion, although the quality of frozen semen still meets the standards for artificial insemination programs, the age factor in bulls needs to be considered for achieving maximum fertility.
\end{abstract}

Keywords: age, bull, DNA fragmentation, fertility, motility.

\section{Introduction}

The quality of frozen semen is one of the main factors that can influence the success of artificial insemination [1]. Good quality frozen semen has a positive effect on increasing fertility [2]. In its application, the quality of frozen semen is also influenced by various factors, one of which is the age of bulls. Bhakat et al. [3] stated that aging can cause a decrease in semen production and quality. Vilakazi and Webb [4] also stated that increasing age in bulls caused testicular tissue degeneration and affected the quality and quantity of semen. Aging will have an impact on decreased motility and increased sperm abnormality [5]. Decreased motility will cause a decrease in the fertilizing ability of sperm [6]. Increased sperm abnormalities, especially major abnormalities are closely related to DNA damage [7]. DNA damage can cause pregnancy failure, reduce the success of implantation and inhibit the development of the embryo [8]. Based on these things, this study aimed to analyze the effect of age of bulls on motility, DNA fragmentation, and their impact on fertility.

\section{Materials and Methods}

The study used eight bulls divided into four groups based on age (group-1: 5-6 years; group-2: 7-8 years; group-3: 9-10 years; group-4: 11-12 years). Ninety-six frozen semen straws in each bull were used for analysis.

\subsection{Sperm Motility}

Analysis of total and progressive motility was carried out using the SpermVision Program (Minitüb, Germany). A total of $6 \mu \mathrm{l}$ of a frozen semen sample was dropped on a glass object and covered with a glass cover. A total of 750-1,000 sperm cells from five fields were evaluated using SpermVision.

\subsection{DNA Fragmentation}

DNA fragmentation analysis was performed using toluidine blue staining [9]. Smear preparations from semen samples were dried and fixed in ethanol and acetone for 60 minutes at $4^{\circ} \mathrm{C}$. The smears were then airdried and hydrolyzed in $0.1 \mathrm{~N} \mathrm{HCl}$ for 5 minutes at $4^{\circ} \mathrm{C}$, and rinsed three times using distilled water (DW), and stained with $0.05 \%$ TB for 5 minutes. After staining was complete, then rinse and observe 500 sperm cells.

* Corresponding author: rhinogil@googlemail.com 
Spermatozoa that have DNA damage will be colored dark blue, while the spermatozoa with DNA that are still normal will be bright blue.

\subsection{Fertility Index}

The fertility index was obtained based on more than 500 artificial insemination services in the field for each bull used. The percentage of pregnant cows at the first insemination (conception rate) is the parameter used to determine the fertility index.

\subsection{Statistical Analysis}

ANOVA statistical analysis was performed using SPSS ver. 25 , and if there were significant differences, then a further analysis was performed using the Tukey. Analysis of the relationship of age with the quality of frozen semen and fertility index was performed using Pearson correlation analysis and linear regression. The data obtained are presented in mean $\pm \mathrm{SD}$.

\section{Results and Discussion}

Good motility is a major component of normal male fertility. Total motility and progressive motility (Figure. 1) showed significantly different results in each bull age group ( $\mathrm{P}<0.05$ ), except that the total motility in group-2 and group-3 showed results that were not statistically different $(\mathrm{P}>0.05)$. Significantly total and progressive motility (Table 1) will decrease with increasing age in cattle $(\mathrm{P}<0.01)$. Sloter et al. [10] reported that sperm motility decreases with age until it reaches $0.8 \%$ per year. This is likely due to a decrease in the function of the post testicular glands [11]. Aitken et al. [12], also added that as we get older there will be a decrease in epididymis function and a change in the function of sperm mitochondria which is very important for sperm motility.

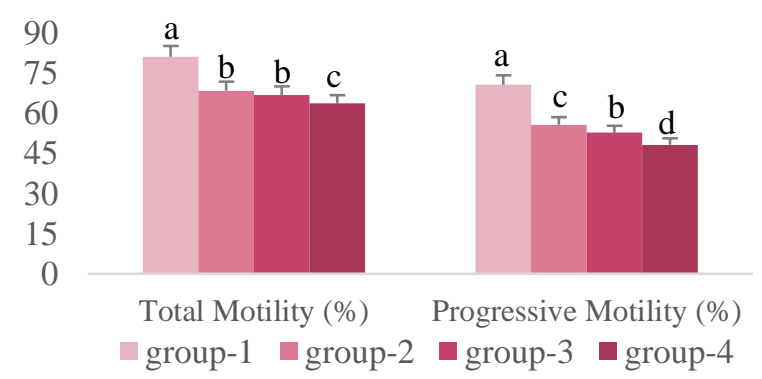

Figure 1. Total and progressive motility in each age group of bulls. a, b, c, d Differing superscripts differ between bull ages within each parameter $(\mathrm{P}<0.05)$.

The average value of total motility was decreased following the older age (group-1, group-2, group-3, group-4) $80.79 \%$ (standard deviation 1.15), $68.14 \%$ (3.45), 66.46\% (4.11), and 63.34\% (3.03). The average value of progressive showed the same pattern, $70.38 \%$ (2.6), 55.54\% (0.82), 52.48\% (2.01), and 48.04\% (0.67). Zewdie et al. [13] stated that the minimum percentage of motility in post-thawing frozen semen is $40 \%$, and this means that although motility decreases with age in bulls, it still meets the minimum standards for artificial insemination.

Table 1. Correlations of age groups with various parameters.

\begin{tabular}{lcc}
\hline \multicolumn{1}{c}{ Category } & $\begin{array}{c}\text { Correlation } \\
\text { coefficient }\end{array}$ & P-value \\
\hline Age versus total motility & -0.790 & $<0.01$ \\
Age versus progressive motility & -0.819 & $<0.01$ \\
Age versus DNA fragmentation & 0.839 & $<0.01$ \\
Age versus fertility index & -0.880 & $<0.01$ \\
\hline
\end{tabular}

Each age group of bulls showed significantly different results on DNA fragmentation $(\mathrm{P}<0.05)$ (Figure. 2 ). Correlation analysis showed that the age of bulls was closely related to DNA fragmentation $(\mathrm{P}<0.01)$ (Table 1$)$. Wyrobek et al. [14] argued that this is due to an increase in oxidative stress over time, and also a decrease in the antioxidant capacity of the epididymis with age [15].

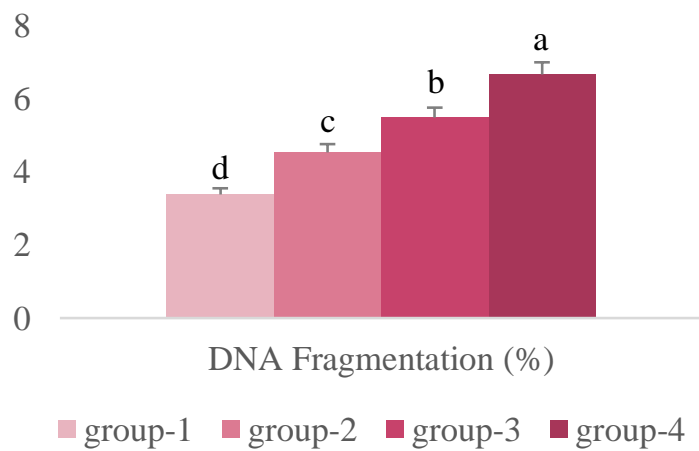

Figure. 2. DNA fragmentation in each age group of bulls. ${ }^{a, b, c, d}$ Differing superscripts differ between bull ages within each parameter $(\mathrm{P}<0.05)$.

The average value of DNA fragmentation was significantly increased in older bulls, 3.33\% (0.96), $4.54 \%$ (0.88), 5.45\% (0.93), and 6.67\% (0.7). Larson-Cook et al. [16] suggested that DNA damage to sperm less than $15 \%$ is still in normal condition, while $15-25 \%$ is included in the low fertility category. Referring to this, despite the increase in DNA damage along with the increasing age of bulls, but the percentage of DNA fragmentation is still in normal conditions.

The results of the correlation analysis show that fertility will decrease from $82 \%$ to $67 \%$ with age in cattle $(\mathrm{P}<0.01)$ (Figure. 3). Diskin [17] revealed that a good fertility index is $60-70 \%$, while Butler [18] stated that a good fertility index must reach $70 \%$. However, the results of the study indicate that the age of the bulls is one of the factors that need to be considered to achieve maximum fertility index. Haris et al. [19] reported that the decrease in fertility due to aging is caused by several factors such as the quality of semen, changes in anatomic organs, and decreased testosterone concentrations which have an impact on decreased libido, erectile dysfunction (ED) and difficulty reaching ejaculation [20]. 


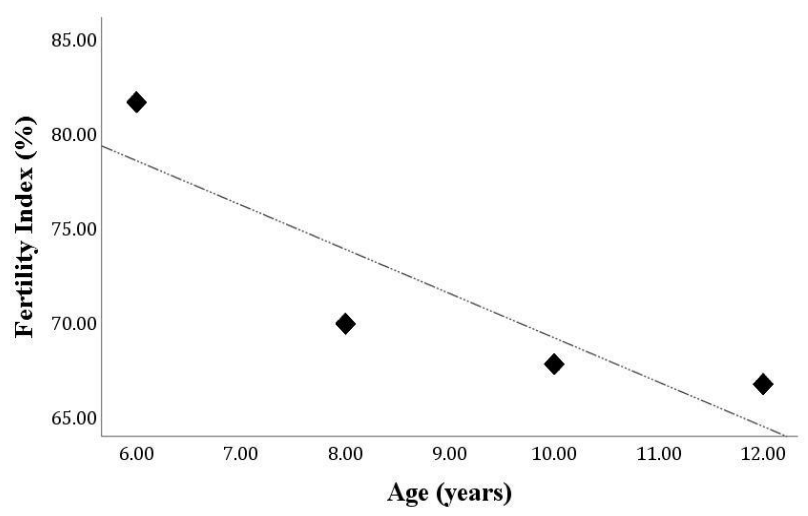

Figure 3. Relationship between age of bulls with fertility index $(\mathrm{P}<0.01)$.

\section{Conclusion}

In conclusion, although the quality of frozen semen still meets the standards for artificial insemination programs, the age factor in bulls needs to be considered for achieving maximum fertility.

\section{Acknowledgments}

This study was funded and supported by the Directorate of Research and Community Service, Directorate General of Higher Education, Ministry of Research, Technology, and Higher Education, the Republic of Indonesia through the PMDSU grant. Moreover, this paper is also supported by USAID through Sustainable Higher Education Research Alliances (SHERA) Program - Center for Collaborative Research Animal Biotechnology and Coral Reef Fisheries (CCR ANBIOCORE).

\section{References}

1. Lemma A: Effect of cryopreservation on sperm quality and fertility, Artificial Insemination in Farm Animals. Milad Manafi, IntechOpen. 2011.

2. Kebede A: Review on Factors Affecting Success of Artificial Insemination. Int J Curr Res Aca Rev. 2018; 6 (5):42-49.

3. Bhakat M, Mohanty TK, Raina VC, et al.: Effect of age and season on semen quality parameters in Sahiwal bulls. Trop Anim Health Prod. 2011; 43 (6):1161-8.

4. Vilakazi DM, Webb EC: Effect of age and season on sperm morphology of Friesland bulls at an artificial insemination centre in South Africa. $S$ Afr J Anim Sci. 2004; 34 (1):62-69.

5. Brito LF, Silva AE, Rodrigues LH, et al.: Effect of environmental factor, age, genotype on sperm production and semen quality in Bos Indicus and Bos Taurus AI bulls in Brazil. Anim Reprod Sci. 2002; 70 (34):181-90.
6. Garner DL, Hafez ES: Spermatozoa and seminal plasma. In: B Hafez, ES Hafez (eds) Reproduction in Farm Animals. Philadelphia: Lippincot William and Wilkins. 2000.

7. Enciso $\mathrm{M}$, Cisale $\mathrm{H}$, Johnston $\mathrm{SD}$, et al:: Major morphological sperm abnormalities in the bull are related to sperm DNA damage. Theriogenology. 2011; 76 (1):23-32.

8. Virro MR, Larson-Cook KL, Evenson DP: Sperm chromatin structure assay (SCSA) parameters are related to fertilization blastocyst development,and on going pregnancy in vitro fertilization and intracytoplasmic sperm injection cycles. Fertil Steril. 2004; 81 (5):1289-95.

9. Kim HS, Kang MJ, Kim SA, et al.: The utility of sperm DNA damage assay using toluidine blue and aniline blue staining in routine semen analysis. Clin Exp Reprod Med. 2013; 40 (1):23-28.

10. Sloter E, Schmid TE, Marchetti F, et al.: Quantitative effects of male age on sperm motion. Hum Reprod. 2006; 21 (11):2868-75.

11. Sartorius GA, Nieschlag E: Paternal age and reproduction. Hum Reprod Update. 2010; 16 (1):65-79.

12. Aitken RJ, Nixon B, Lin M, et al.: Proteomic changes in mammalian spermatozoa during epididymal maturation. Asian J Androl. 2007; 9 (4):554-64.

13. Zewdie E, Deneke N, FikreMariam D, et al.: Guidelines and procedures on bovine semen production. Addis Ababa: NAIC. 2005.

14. Wyrobek AJ, Eskenazi B, Young S, et al.: Advancing age has differential effects on DNA damage, chromatin integrity, gene mutations, and aneuploidies in sperm. Proc Natl Acad Sci. 2006; 103 (25):9601-9606.

15. Zubkova EV, Robaire B: Effects of ageing on spermatozoal chromatin and its sensitivity to in vivo and in vitro oxidative challenge in the Brown Norway rat. Hum Reprod. 2006; 21 (11):2901-10.

16. Larson-Cook KL, Brannian JD, Hansen KA, et al: Relationship between the outcomes of assisted reproductive techniques and sperm DNA fragmentation as measured by the sperm chromatin structure assay. Fertil Steril. 2003; 80 (4):895-902.

17. Diskin MG: Optimizing reproductive performance of beef cows and replacement heifers. Animal. 2014; Suppl 1:27-39.

18. Butler S: Nutritional management to optimize fertility of dairy cows in pasture-based systems. Animal. 2014; Suppl 1:15-26.

19. Haris ID, Fronczak C, Roth L, et al:: Fertility and the Aging Male. Rev Urol. 2011; 13 (4):184-190.

20. Feldman HA, Goldstein I, Hatzichristou DG, et al.: Impotence and its medical and psychosocial correlates: results of the Massachusetts Male Aging Study. J Urol. 1994; 151 (1):54-61. 